\title{
The Developmental Stages of Some Species of the Japanese Pentatomoidea (Hemiptera)
}

\author{
XIV. Developmental Stages of Graphosoma and its Allied \\ Genera of Japan (Pentatomidae)
}

\author{
By Takashi KoBAYASHI
}

Tohoku National Agricultural Experiment Station, Morioka

The subfamily Podopinae (=Graphosominae) is represented in Japan by seven species of four genera, namely, Graphosoma rubrolineatum (WeSTwOOD), Dybowskyia reticulata (Dallas), Scotinophara lurida (Burmeister), S. scottii Horváth, S. horvathi Distant, S. scutellata Scotr and Neocazira confragrosa Distant. Among these seven species, the second to the fifth species have already been reported on their developmental stages by the author (1951, 1963), although those of the last two species have not been studied yet. In the present paper, the developmental stages of Graphosoma rubrolineatum (WESTwood) which is a serious pest of Umbelliferous vegetables are given, together with its brief bionomics and the diagnoses of the subfamily Podopinae and its three genera except Neocazira.

Prior to entering into the subject, I wish to express my sincere thanks to Professor T. Ishinara, Mr. H. Hasegawa and Dr. D. Leston who kindly adviced me during the course of the present work.

\section{THE DIAGNOSES OF THE SUBFAMILY PODOPINAE}

\section{A. The egg}

Rather short ovoid or ellipsoidal. Chorion white or whitish subhyaline, furnished with a conspicuous reticulation, on which spines or lamellate projections are placed, or a faint reticulation and small punctures. Micropylar projections white or whitish translucent, capitate, short, barely bended inward, about 25 to 45 in number. Eggopener well-chitinized T-shaped, with membraneous appendages which are centrally transparent, inferiorly and infero-laterally grayish brown or whitish. Egg-mass ordinarily consists of about 3 to 14 eggs, arranged in two or one row or irregularly.

\section{B. The larva}

Body not depressed in all the instars, and short elliptical in the 1st instar, elliptical or ovate in the 2nd instar, elliptical, ovate or roundish in the 3 rd instar, elliptical or roundish in the 4th instar, elliptical or anteriorly angulate and posteriorly roundish in the 5th instar. Stigmata placed inside the connexiva of abdominal segments from the 2nd to the 7th. Ventral abdominal trichobothria situated posterior to stigma of each abdominal segment from the 3rd to the 7th. Body above furnished with massive punctures or dots and short hairs except dorsal surface of Dybowskyia. Median lobe ordinarily moderate in size in stages younger than the 2 nd or the 3 rd instars inclusive, but small in stages older than the 3rd or the 4th instars, except Scotinophara lurida which have moderate median lobe in all the instars. Lateral lobes: moderate in the 1st instar of all the species, in the 2nd instar of Graphosoma and in the 2nd and the 3rd instars of Dybowskyia, rather slender in stages older than the 2nd of Scotinophara, rather broad in the 3rd to the 5th instars of Graphosoma and in the

(Received for publication, December 26, 1964) 
4 th and the 5 th instars of Dybowskyia, longer than median lobe in stages older than the 2nd instar in Graphosoma, the 3rd instar in Dybowskyia and than the 4 th instar in Scotinophara scottii and $S$. horvathi, the apices contact with each other at apex of median lobe in the 5th instar of Graphosoma and Dybowskyia. Antenniferous tubercles undeveloped or developed. Pronotum narrower than mesonotum. Metanotum wider than mesonotum in the 1st, or the 1st and the 2nd instars, but that narrower in the 2nd or the 3 rd to the 5 th instars. Lateral margins of thorax laevigate and gently arched in the 1st instar, laevigate or serrated and gently arched in the 2nd to the 5 th instars. Dorsal abdominal plates possessed with odoriferous gland orifices comparatively small or moderate, the anterior one rather fusiform constricted medially, the middle one rather trapezium of which the anterior margin is longer than the posterior margin, the posterior one generally elliptical of which the posterior margin is convex and the anterior margin is almost straight, or trapezium like the middle one. Connexiva moderate or comparatively small, semi-circular or quadrate, with laevigate or serrated outer margins. External sexual character is recognizable in the 4 th and the 5 th instars. Female larva of the 4 th instar with a triangular concavity in the middle of posterior margin of the 8th sternite. Female larva of the 5th instar with a longitudinal line and a triangular structure in the middle of caudal half and posterior margin of the 8th abdominal sternite. The male larvae without such structures.

C. Key to the genera

a. The egg

1(4) Chorion furnished with a distinct reticulation, without punctures.

2(3) Reticulation -small mesh, with numerous minute spines........... Graphosoma

3(2) Reticulation large mesh, with irregular lamellae. .............. Dybowskyia

4(1) Chorion sculptured with small punctures and a faint reticulation. .......... b. The larva

1(4) In the 1st instar, dorsal abdominal plates of the 1st and the 2nd segments indistinct; in the 2 nd to the 5 th instars, thoracic lateral margins laevigate.

2(3) Large, abdomen furnished with asymmetric large dots. ...........Graphosoma

3(2) Small, abdomen furnished with round punctures, without asymmetric large dots. ............................. Dybowskyia

4(1) In the 1st instar, dorsal abdominal plates of the 1st and the 2nd segments distinct; in the 2nd to the 5 th instars, thoracic lateral margins serrated...... Scotinophara

\section{THE DIAGNOSES OF THE GENUS GRAPHOSOMA}

The genus Graphosoma is represented in Japan by only one species, Graphosoma rubrolineatum (WESTwOOD).

Graphosoma rubrolineatum (WESTWOOD)

[Nom. Jap.: Akasuji-kamemushi]

1837 Scutellera rubrolineata Westwood, Hope Cat. $1: 12$.

1861 Graphosoma crassa Motschulsky, Etudes Ent. X : 22.

1903 G. rubrolineatum HoRvÁth, Termesz. Füzet. $3: 143$; Ann. M. N. Hang. $1: 346$, 352.

1906 G. rubrolineatum Oshanin, Palae. Hem. (Het.), I : 67.

1909 G. rubrolineata Kirkaldy, Cat. Hem. $1: 224$ (cat.).

1935 G. rubrolineatum Hoffmann, Cat. Cert.

Scut. China etc. Lingnan Univ. Sci. Bul. $7: 39$.

1936 G. rubrolineatum TAKAHASHI, Sosaigaichu-kakuron 81 83 (egg-mass, 5th instar larva, bionomics).

The present species which is distributed in the whole land of Japan, Loochoo, Korea, China and Siberia has one generation a year. The adults hibernated at the root of grass and other places appear from May or June, and harm seeds of carrot, parsely, parsnip, celery and other Umbelliferous plants. The oviposition is taken place from June to August, and the 


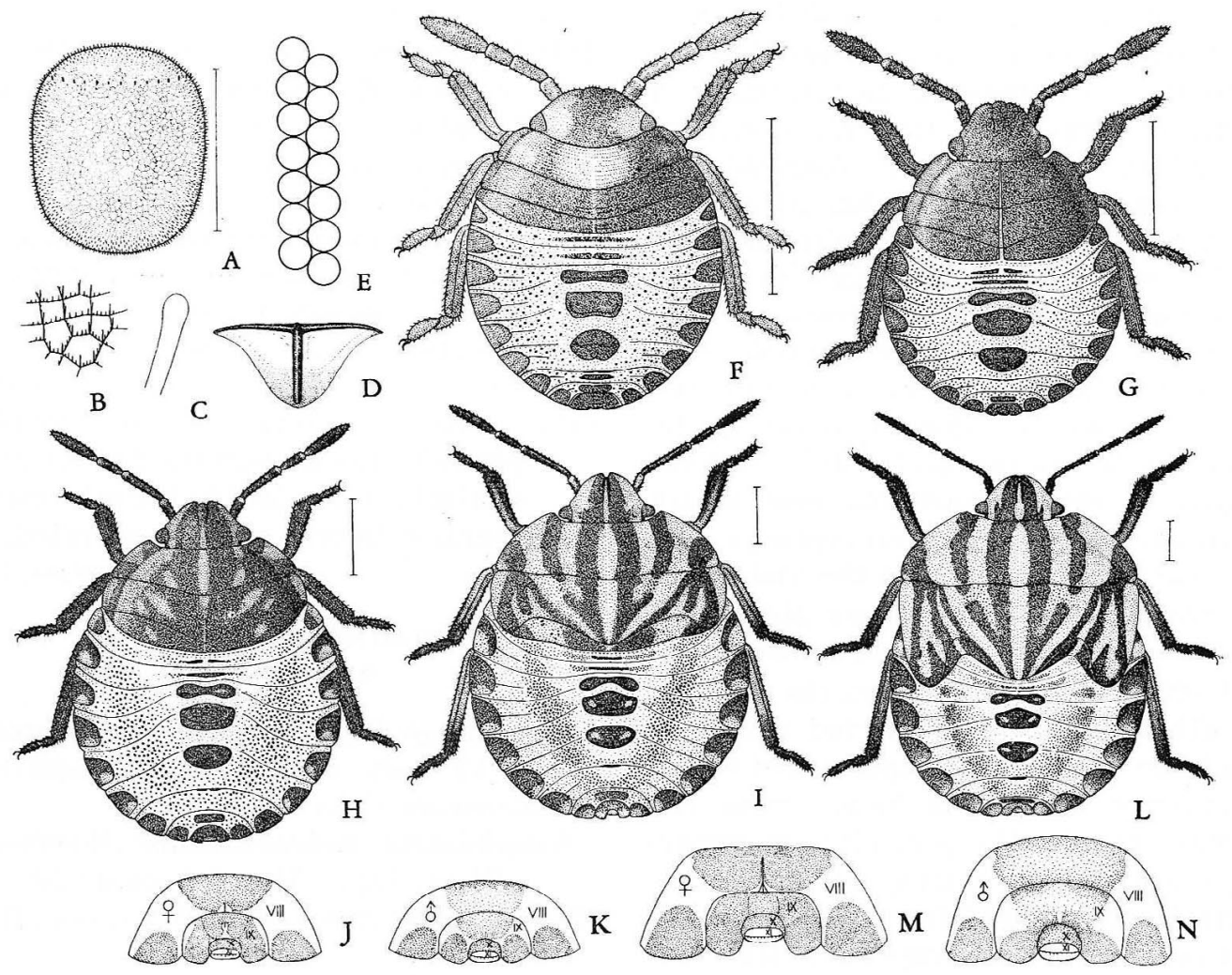

Fig. 1. Graphosoma rubrolineatum (Westwood) [Nom. Jap.: Akasuji-kamemushi]

A: egg, B: reticulation on chorion, C: micropylar projection, D: egg-opener, E: egg-mass,

$F$ : the first instar, $G$ : the second instar, $H$ : the third instar, $I$ : the fourth instar, $\mathrm{J}$ : female character on distal sterna of the fourth instar larva, $\mathrm{K}$ : male charcter in the same instar larva, L: the fifth instar, M: female character on distal sterna of the fifth instar larva, $\mathrm{N}$ : male character in the same instar larva. (calibration $1 \mathrm{~mm}$ )

new adults emerge from August to September.

A. The egg [Fig. 1: A $\sim \mathrm{E}$ ]

Length about 1.1 to $1.3 \mathrm{~mm}$, diameter about 0.9 to $1.0 \mathrm{~mm}$, rather short ovoid, somewhat bigger upperly; uniformly white at first, pale yellowish brown later and a darkish egg-opener and reddish eye-spots appear beneath chorion before hatching. Chorion white, with numerous, minute, but stout, whitish spines on a distinct reticulation which is small mesh. Micropylar projections whitish translucent, about $59 \mu$, about 30 in number. Eggopener T-shaped, about $0.20 \mathrm{~mm}$ vertically, about $0.41 \mathrm{~mm}$ transversely, blackish brown except somewhat paler upper part of vertical axis, with membraneous appendages which are transparent medially, darkish inferiorly and light grayish inferolaterally. The eggs are deposited on flower-stalks or seeds of the host-plants, ordinarily making a mass of two rows, consisting of about 14 eggs.

B. The larva [Fig. 1: $\mathrm{F} \sim \mathrm{N}$ ]

Key to the instars

1(6) Wing-pads unrecognized.

2(3) Eyes not prominent. ...The 1st instar

3(2) Eyes clearly protruding.

4(5) Metanotum which is narrower than mesonotum with lateral margins which are clearly distinguishable from the posterior margin.

The 2nd instar 
5(4) Metanotum with lateral margins which are pointed and indistinguishable from the posterior margin. …...

6(1) Anterior wing-pads developed.

7(8) Posterior wing-pads undeveloped. ...... .............................The 4th instar

8(7) Posterior wing-pads conspicuously developed. ............... The 5th instar

The first instar [Fig. 1: F]

Body short elliptical, about $1.6 \mathrm{~mm}$ in length. Outer margins of head, thorax and of connexiva laevigate and gently arched (through all the instars). Body above very sparsely with short hairs (through all the instars). Head impunctate (1st 3rd instars), brownish black except a pair of dark orange yellow markings inside eyes; median lobe longer than lateral lobes. Thorax impunctate, dark brown except the middle portion and lateral parts of pronotum which are light brown. Abdomen mostly light brown, medially light orange yellowish, with an indistinct dorsal abdominal plate on the 1 st and the 2nd segments respectively, distinct one on the 8th segment (through all the instars), and sparsely furnished with asymmetric black dots. Dorsal abdominal plates impunctate (1st 3rd instars), dark brown or dark; the one possessed with odoriferous gland orifices relatively small, the anterior one is widest (through all the instars) and baculiform, weakly constricted medially, the posterior one is narrowest (through ald the instars) but longest and elliptical. Connexiva impunctate (through all the instars), dark brown or dark. Eyes dark red (through all the instars). Antennae and legs grayish brown, but the bases of tibiae pale yellow-brownish. The ratio of pro- : meso- : metanotum about $3.0: 2.25: 1$. The ratio of the thoracic median length and the thoracic width at anterior margin of mesonotum about $1: 2.25$. The ratio of the antennal segments about I : II : III : IV $=1: 1.4: 0.9: 2.6$.

The second instar [Fig, 1: G]

Body short ovate, about $2.5 \mathrm{~mm}$ in length. Head trapezium, with lateral lobes which are longer than median lobe (2nd $\sim 5$ th instars). Thorax sparsely punctured with minute punctures (2nd $\sim 5$ th instars); metanotum narrower than mesonotum, but its lateral margins not pungent and clearly distinguishable from the posterior margin. Abdomen roundish, light brown, with red segmental sutures, densely furnished with asymmetric, comparatively large, black dots. Dorsal abdominal plate possessed with anterior odoriferous gland orifices spindle-shaped, conspicuously constricted medially (2nd $\sim 5$ th instars); the one possessed with posterior odoriferous gland orifices elliptical, of which the posterior margin is considerably convexed than the anterior margin (2nd 5 th instars). Head, thorax, dorsal abdominal plates and connexiva nearly black except lateral parts of face which are light brownish, with a faint red-copperish luster. Of antenna, the 1st segment mostly dark brown, apically lighter, the 2nd to the 4th segments mostly reddish black, antennal junctions at both ends of the 3rd segment red, and the apex somewhat paler (2nd, 3rd instars). Legs brownish black, with femora which are proximally more or less lighter in hue (2nd, 3rd instars). The ratio of pro- : meso- : metanotum about $4.8: 4.0: 1$. The ratio of the thoracic median length and the thoracic width at anterior margin of mesonotum about $1: 1.75$. The ratio of the antennal segments about I : II : III : IV $=1: 1.7: 1.1: 2.0$.

The third instar [Fig. 1: H]

Body roundish (3rd, 4 th instars), about $4.0 \mathrm{~mm}$ in length. Head wide trapezium; lateral lobes more or less longer than median lobe which is considerably narrow. Metanotum narrower than mesonotum, and its lateral margins pungent and indistinguishable from the posterior margin. Head and thorax mostly brownish black, with a feeble red-copperish luster, and orange-yellow markings often appear on the median line, on lateral margins of head and thorax and on intermediate 
portions between the median line and lateral margins of thorax as figured. Abdomen pale yellowish brown, faintly tinted with light greenish tinge on the most parts, but light reddish at interspaces between each dorsal abdominal plate and between each connexivum, and reddish on segmental sutures near connexiva, densely, especially on intermediate parts between dorsal abdominal plates and connexiva, furnished with asymmetric, angular, comparatively large, black dots. Dorsal abdominal plates nearly black with a copperish luster. Connexiva mostly brownish black, and an orange-yellow marking often appears medio-posteriorly respectively. The ratio of pro- : meso- : metanotum about $5.1: 5.3: 1$. The ratio of the thoracic median length and the thoracic width at anterior margin of mesonotum about $1: 1.75$. The ratio of the antennal segments about I : II : III $:$ IV $=1: 1.85: 1.1$ : 2.0.

The fourth instar [Fig. 1: $\mathrm{I} \sim \mathrm{K}$ ]

Body length about $5.8 \mathrm{~mm}$. Head roundish triangular, scarcely with minute punctures (4th, 5th instars); lateral lobes wide and conspicuously longer than median lobe which is extremely narrow. Thorax wide, with developed anterior wing-pads, but posterior wing-pads undeyeloped. Head, thorax and connexiva black with a faint red-copperish luster, light orange yellow stripes, of which three are present on head and nine on thorax, and the same colour marking on each connexivum as the former instar (4th, 5th instars). Abdomen mostly pale yellowish brown, feebly tinted with light green, but, medially whitish, interspaces between each connexivum yellowish, segmental sutures near connexiva reddish, densely furnished with asymmetric, angular, comparatively large, black dots on intermediate parts between dorsal abdominal plates and connexiva (4th, 5th instars). Dorsal abdominal plates black, with a faint red-copperish luster, except a light brown or whitish portion anterior to each odoriferous gland orifice, and scarcely with minute punc- tures (4th, 5th instars). Of antenna, the 1st segment blackish brown, the 2nd to the 4th segments piceous, antennal junctions at both ends of the 3rd segment reddish. Femora mainly light brown, with blackish brown apices. Tibiae mostly brown or light brown, with black apices and black tarsi. External sexual characters: female with an indistinct triangular concavity, which has a black longitudinal line in the middle of posterior margin of the 8 th sternite and an indistinct longitudinal concavity in the middle of posterior half of the 9 th sternite; male without such structures. The ratio of pro- : meso- : metanotum about $10.0: 10.8: 1$. The ratio of the thoracic median length and the thoracic width at anterior margin of mesonotum about $1: 1.71$. The ratio of the antennal segments about I : II : III $:$ IV $=1: 2.4: 1.4: 2.3$.

The fifth instar [Fig. 1: $\mathrm{L} \sim \mathrm{N}$ ]

Body rather angulate anteriorly, roundish posteriorly, about $8.3 \mathrm{~mm}$ in length. Head roundish triangular; lateral lobes wide, conspicuously longer than median lobe which is extremely narrow, and contiguous to each other at apex, leaving: a triangular cavity between these and median lobe. Anterior and posterior wing pads conspicuously developed. Colouration similar to the former instar, but light orange yellowish stripes become eleven in number as figured. Two ventral abdominal trichobothria situated abreast right posterior to stigma of each segment from the 3 rd to the $7 \mathrm{th}$, in the 3 rd to the 5th instars. External sexual characters : in female, a triangular concavity recognized at posterior margin of the 8th sternite, a longitudinal vallecula placed at posterior two-third in the middle of this sternite, and posterior margin of the 10th abdominal segment situated considerably cepharad to posterior margin of connexiva of the 9th segment; in male, the triangular concavity and the longitudinal vallecula unrecognized, and posterior margin of the 10th abdominal segment situated almost on the same line 
with posterior margin of connexiva of the 9th segment. The ratio of pro-: meso- : metanotum about $1: 1.42: 0$. The ratio of the thoracic median length and the thoracic width at anterior margin of mesonotum about $1: 1.45$. The ratio of the antennal segments about I : II : III : IV $=1: 2.3 ; 1.3: 2.1$.

\section{THE DIAGNOSES OF THE GENUS $D Y B O W S K Y I A$}

The genus Dybowskyia is also represented in Japan by only one species Dybowskyia reticulata (DALLAS) which is distributed in Honshu, Shikoku and Kyushu of Japan, China, Amur district etc. and parasitic on seeds of Torilis japonica (HoutT.) DC.

\section{A. The egg}

Elliptical, whitish, with a pearly luster, furnished with a large mesh reticulation, on.. which whitish, irregular, lamellate projections are placed. Micropylar projections very short, almost hyaline, about 38 to 40 in number. Egg-opener blackish brown, with membraneous appendages which are medially transparent, inferiorly and infero-laterally whitish translucent. The eggs are deposited, making a row or irregular mass of a few to several eggs, or seperately, on seeds, flower-stalks or the under surface of leaves of the hostplant.

\section{B. The larva}

a. Key to the instars

1(6) Wing-pads unrecognized.

2(3) Eyes not prominent. ... The 1st instar

3(2) Eyes clearly protruding.

4(5) Metanotum wider than mesonotum. ............................. The 2nd instar

5(4) Metanotum narrower than mesonotum …................ The 3rd instar

6(1) Anterior wing-pads developed.

7(8) Posterior wing-pads undeveloped ....... .............................The 4th instar

8(7) Posterior wing-pads conspicuously developed.................. The 5th instar

This key is available to the following genus Scotinophara too.

b. Diagnoses of each instar larva Body short elliptical in the 1st instar, ovate in the 2nd and the 3rd instars, rather roundish in the 4 th and the 5 th instars. Body above densely furnished with black massive punctures; dorsal surface scarcely, ventral surface very sparsely furnished with short hairs. Two ventral abdominal trichobothria situated abreast right posterior to stigma of each segment from the 3 rd to the 7 th, in the 3 rd to the 5 th instars. Head: median lobe longer than lateral lobes in, the 1st instar, as wide as in the 2nd instar, with gently arched anterior margin, small and shorter than lateral lobes in the 3rd to the 5th instars; lateral lobes rather large, the apices apart each other in the 1 st to the 4th instars, meeting in the 5th instar at apex of median lobe; antenniferous tubercles undeveloped. Thorax: rather wide in the 4 th and the 5 th instars; metanotum wider than mesonotum in the 1st and the 2nd instars, but that narrower in the 3 rd to the 5 th instars; lateral margins laevigate and gently arched; a pair of impunctate whitish portions appear on the base of primordial scutellum in the 4 th and the 5th instars, and also on the middle of pronotum in the 5 th instar. Abdomen: dorsal abdominal plates possessed with odoriferous gland orifices moderate in size, the anterior one, compared with the middle one, almost as wide as in the 1st and the 2nd instars, narrower in the $3 r d$ to the 5 th instars, the posterior one rather trapezium like the middle one in the 1st instar, rather elliptical of which the posterior margin is convex and the anterior margin is almost straight in the 2nd to the 5 th instars; connexiva rather quadrate in the 1st and the 2nd instars, rather semi-circular in the 3rd to the 5 th instars, comparatively small in the 1st to the 3rd instars, moderate in the 4 th and the 5 th instars.

\section{THE DIAGNOSES OF THE GENUS SCOTINOPHARA}

The genus Scotingphara is represented in Japan by, four species, Scotinopharg lurida (BURMEISTER) which is widely dis; 
tributed in Japan (Honshu, Shikoku, Kyushu), Loocho, Manchuria, China, Indo-China, Assam, India, Celebes etc. and severely damages a rice plant, $S$. horvathi Distant, $S$. scottii Horváth and S. scutellata ScotT.

\section{A. The egg}

Short ovoid, somewhat bigger upperly. Chorion white, sculptured with a faint reticulation and small punctures. Micropylar projections very short, white, about 35 to 45 in number. Egg-opener with membraneous appendages which are transparent centrally, grayish brown inferiorly and infero-laterally. Egg-mass ordinarily consists of about 6 to 14 eggs, arranged in two rows, and is attached to leaf-blades or leaf-sheaths of the host-plants.

B. The larva

Body elliptical, rather short in the 1st instar. Body above furnished with dark brownish, massive punctures and light brown short hairs. Ventral abdominal trichobothria, in S. lurida and $S$. horvathi exist two, of which the inner one is placed right posterior to stigma of each segment from the 3 rd to the 7 th and the outer one is situated postero-exterior to the inner one, however that in $S$. scottii seems to be only one, placed right posterior to each stigma of the same five segments, in the 4 th and the 5th instars. Head: median lobe gently arched anteriorly; lateral lobes rather slender in the 2nd to the 5 th instars, and these compared with median lobe, shorter in all the instars of S. lurida, the 1 st to the 3 rd instars of $S$. scottii and in the 1st and the 2nd instars of $S$. horvathi, as wide as in the 3rd instar of $S$. horvathi, and longer in the 4 th and the 5 th instars of $S$. scottii and $S$. horvathi; antenniferous tubercles developed. Thorax : rather narrower or moderate in the 4 th and the 5th instars; pronotum with well angulated front angles in the 5 th instar; lateral margins serrated in the 2nd to the 5th instars. Abdomen: dorsal abdominal plates possessed with odoriferous gland orifices moderate in size, the anterior one almost fusiform, rather stout, weakly constricted medially and as wide as the middle one in the 1st instar, while the plate in the 2 nd to the 5 th instars rather slender, conspicuously constricted medially and narrower than the middle one; connexiva comparatively small, semi-circular. External sexual character: female of the 4 th instar with an indistinct triangular concavity in the middle of posterior margin of the 8th sternite; female of the 5th instar with a brown longitudinal line in the middle of posterior half of the 8th sternite and a rather distinct triangular structure in the middle of posterior margin of this sternite; male larvae without such structures. Colouration ordinarily light to dark brownish.

The eggs and larvae of three known species, S. lurida (Burmeister), S. scottii HoRváth and $S$. horvathi Distant are distinguishable each other by the key presented in the author's previous report No. XI (1963).

\section{SUMMARY}

The developmental stages of Graphosoma rubrolineatum (WeSTwOoD) which is injurious to Umbelliferous vegetable, together with its brief bionomics and the diagnoses of its allied three genera and their subfamily Podopinae (=Graphosominae) are given in the present paper. In Japan, the genera Graphosoma and Dybowskyia are represented by only one species respectively, and the genus Scotinophara is composed of four species, including $S$. lurida (Burmeister), a serious pest of a rice plant. The eggs and larvae of these three genera and three known species of the genus Scotinophara are discernible each other by the keys presented in the present text and the author's previous report No. XI (1963).

\section{REFERENCES}

Kobayashi, T. (1951) Trans. Shikoku Ent. Soc $2: 7 \sim 16$

KовауAShi, T. (1963) Japanese Jour. Appl. Ent. Zool. $7: 70 \sim 78$.

TAKahashi, S. (1936) Sosai-gaichu-kakuron, 451pp. (in Japanese), Meibundo, Tokyo. 


\author{
摘要 \\ 日本産カメムシ上科の幼期に関する研究 \\ 第 14 報 Graphosoma およびその近縁属の幼期 \\ 小林尚
}

東北農業試験場栽培第二部虫害研究室

日本のアカスジカメムシ亜科はニンジン等のからかさ ばな科作物やイネ等のい科作物を害する重要害虫を含 む 4 属 7 種よりなり, Neocazira 以外の 3 属は次の検索 表によって識別できる。

a. 卵

1(4) 卵殼には点刻がなく, 明暸な網状構造がある。

2(3) 網状構造はこまかく, 多数の小刺を装う

Graphosoma

3(2) 網状構造はあらく, 不規則なひだ状突起を装う… Dybowskyia

4(1) 卵殼には小点刻とかすかな網状構造がある……... Scotinophara

b. 幼 虫

1(4) 第 1 令幼虫では第 1 および第 2 腹節の腹背板が不 明瞭, 第 $2 \sim 5$ 令幼虫では胸部側縁が平滑。

2(3) 大形，腹部には不整形の大形斑点を装う
3(2) 小形，腹部には不整形の大形斑点がなく, 円形の 点刻を装う Dybowskyia

4(1) 第 1 令幼虫では第 1 および第 2 腹節の腹背板が明 瞭, 第 $2 \sim 5$ 令幼虫では胸部側縁が鋸歯状……...

Scotinophara

Graphosoma 属および Dybowskyia 属はとれぞれ 1 種, Graphosoma rubrolineatum (WeSTwOod) アカス ジカメムシおよび Dybowskyia reticulata (DALLAs) 八 ナダカカメムシのみからなるが, Scotinophara 属は 4 種, Scotinophara lurida (BURmeIster) クロカメム シ, S. scottii HoRváth ヒメクロカメムシ, S. horvathi DistanT オオクロカメムシおよび S. scutellata Scotr からなり，このうちの既知の 3 種，すなわちク ロカメムシ，ヒメクロカメムシおよびオオクロカメムシ は筆者がさきに報告した第 11 報（1963）の検索表で互 に識別できる。

\title{
Graphosoma
}

\section{新 刊 紹. 介}

Proceedings of the First International Congress of Acarology (1964), B 5 判, 439 ページ, \$ 12.25, Acarologia ( 8 bis, Avenue Thiers, La Varenne (Seine), France) 発行

第 1 回国際ダ二学会議（1963年 9 月 2〜7 日,コロラ ド州立大学で開催された）の“Proceedings”が出版 された。ての会議で発表された, 分類・生態・生理・行 動・遗伝・医学・獣医学および農業上のダニなどの諸分 野にわたる 62 論文が登載されている(少数の論文は要約 のみ登載)。との中にはダ二研究の 新しい方向をうち出 した多数の重要な論文も含んで扣り，純粋扣よび応用ダ 二学の最近の動向を知るのに便利である。農業関係ダニ
部会で発表された論文はこの中 13 論文であるが，植物 ダニに関連する研究は他の部会の論文中にも見出され る。本書には, 他に会議出席者の写真数枚・序文・会議 の諸記録・参加者 146 人の名簿 · 開会演説などがのって いる。第 1 回国際ダ二学会議の記録が出版されれば入手 したいから出たら教えてはしいという方々が多いのでて こに紹介した。な打，本書は国際ダ二学尓誌“Acarologia " の第 6 巻の特別号として出版された（ペーシは 新たに 1 頁から始まっている）が，ての雓誌の定期購読 者であっても別に代金を払わないと本書は買えないはず である。

(北大理 江原昭三) 